This is an Accepted Manuscript of an article published by Taylor \& Francis in Journal of War and Culture Studies on 26 September 2017, available online:

http://www.tandfonline.com/10.1080/17526272.2017.1369722. 


\title{
Anzac Anxieties: Rupture, Continuity and Authenticity in the Commemoration of Australian War Dead at Fromelles
}

Key words: World War I; Fromelles; Mass Graves; Memory; Anzac

\begin{abstract}
The Battle of Fromelles in Northern France was launched in July 1916. There were 5,533 Australian casualties and in the immediate aftermath of the battle, German burial parties buried Allied dead in unmarked pits and the whereabouts of some were forgotten. Recent archaeological and scientific work has resulted in the belated recovery and reburial of these bodies with a new, purpose-built CWGC Cemetery inaugurated in the village of Fromelles in 2010.

This article explores the anxieties that the relatives experience during the exhumation and reburial of the dead. These anxieties are allayed, in part, by the unique commemorative culture that has developed over generations in Fromelles. This article will examine the tension between the impetus to preserve the authentic bond fostered between individuals and communities in Fromelles and Australia, and the opposing impetus for greater official recognition, and the investment of state resources, in the military heritage of Fromelles.
\end{abstract}

\section{Introduction}

The Battle of Fromelles in Northern France began on the $19^{\text {th }}$ July 1916. The first major battle fought by Australian troops on the Western Front, it resulted in catastrophic loss of life. As well as German and British losses, there were 5,533 Australian casualties and it has been described as 'the worst 24 hours in Australia's history' (Cobb, 2007; Corfield, 2009). The majority of the Australian dead were recovered at the time, or shortly after the war, and gathered at a collective burial site, the Commonwealth War Graves Commission (CWGC) cemetery known as VC Corner, close to Fromelles. However, this left many bodies unaccounted for. In the immediate aftermath of the battle, German burial parties buried some Allied dead in unmarked pits. The existence of these missing mass graves was initially denied, as it was thought that all the dead had been recovered. The cemetery at VC Corner does not take the usual form of marked grave plots with headstones, because the losses of the battle were so heavy, and the remains of many were in poor condition. Instead, there is a shared monument naming the fallen with hundreds of unmarked group graves surrounding it. The monument at VC Corner is also dedicated to those who died at Fromelles but have no known grave.

Through the remarkable initiative of Australian amateur historian, Lambis Englezos, it was demonstrated that not all the remains had been recovered immediately post-war, and the probable location of the missing bodies was identified through the examination of aerial photographs (Corfield, 2009; Lindsay, 2008). Following a sustained campaign by amateur historians, relatives of the dead, and a wider community of supporters, the suspected location of these burial pits was investigated and the existence of mass graves was confirmed (Pollard et al. 2007; Lindsay, 2008). This campaign became contentious at times due the perceived resistance by the army to investigate the graves. Although 
there are conventions against prospecting for soldier's remains on the Western Front, the compelling evidence for the location these mass graves and the identity of those buried in them, meant this was deemed an exceptional case and the exhumations went ahead as an Australian, British and French collaboration.

The subsequent archaeological and scientific work has resulted in the excavation, examination and reburial of 250 Allied soldiers (Jones, 2010; Loe, 2010). Nearly two thirds of the Australian soldiers have now been positively identified using DNA analysis. The investigation was accompanied by large-scale media coverage and a public outreach programme to invite donations of DNA samples from relatives of the dead, generating very intense engagement from some families (Scully and Woodward, 2012). The Australian Army, the CWGC and scientific practitioners, coordinated this process under the auspices of the 'Fromelles Project'. A new, purpose-built CWGC cemetery was inaugurated in the village of Fromelles in 2010 and has become a key memorial destination for relatives of the dead, and for Australians visiting the Western Front (Summers, 2010). Given the historical evidence for the probable identities of the dead, and the potential to attain unique identifications through DNA analysis, it was decided to construct a new cemetery with the more conventional format of individuallymarked plots and headstones. Following the remarkable technical success of both the excavation and the subsequent laboratory analysis, the majority of these headstones now bear the name of the individual soldier buried beneath them (Renshaw, 2013).

This paper is based on semi-structured recorded interviews with over sixty relatives of the dead soldiers, which were conducted face-to-face in Sydney and Canberra, Australia and in France in 2011 and 2012. The invitation to participate was circulated via the Fromelles Project coordinators. Participants included a broad cross-section of those engaged in the project at different stages in the process, and no other selection criteria was applied, other than they were registered as a potential relative with the Fromelles Project. The majority had received confirmation that a relative had been identified through DNA analysis, whilst others were still awaiting news. Many had been to Fromelles as part of the inaugural ceremony, or on private family visits. Others followed events more remotely, through the news media, or accounts of visits to Fromelles shared by family members. In attributing interview excerpts in this paper, the speakers' names have been changed to protect their identity.

\section{Rupture, Continuity and Authenticity at Fromelles}

This article will explore several related themes: the rupture inherent in any exhumation and reburial of the dead; the resulting concern with ensuring elements of continuity and tradition in the commemoration of the dead; and an associated preoccupation with the authenticity of mourning and memory for those that are long dead. The exhumation of mass graves is an inherently destructive act, in that, once disturbed, the old resting place of the bodies can never be recreated. The relocation of the dead in a new burial site, with accompanying funeral rituals and monuments, is a rite of passage that consolidates the changed status of the bodies (Verdery, 1999). This rite underscores a rupture with the past, and eases the anxieties that this rupture provokes.

There is a clear tension or paradox between the desire for a rupture with the past and the desire for continuity contained within many of the informants' reflective comments 
on the exhumations at Fromelles. It is important to remember that the exhumations at Fromelles resulted (in part) from a sustained campaign by a coalition of interested historians, relatives of the dead, and their supporters (Renshaw, 2013). It is apparent from my interviews that part of the energy of this campaign drew on the conviction that the status of the dead in unmarked mass graves was untenable and that it was imperative the bodies be recovered and formally reburied. When relatives discussed these graves, the dead were characterized as lost, and lacking the recognition and honour that they deserved. A further complication is that the group graves at VC Corner are at odds with contemporary military burial practices and sensibilities, which can be broadly characterized as shifting in emphasis from the collective to the individual (Wagner and Rosenblatt, 2016, 241). The capacity of modern DNA technology to potentially individuate the dead from the mass graves at Fromelles represented a double rupture in the status of the dead, moving them from the lost graves, and breaking with the form of the existing CWGC cemetery for this battle (Renshaw, 2013). However, despite the status of the dead in unmarked mass graves being untenable for the relatives, and the wider public, there is also a strong desire within the Fromelles Project to maintain elements of continuity for the dead. The treatment of the dead, both by the authorities and relatives reflects an impetus to establish, and repeatedly represent, a series of recursive links between the old and new burials of the dead at Fromelles, which necessitates a more detailed exploration.

In the case of Fromelles, there are three significant features that increase the tensions between rupture and continuity inherent in exhumation, and provoke anxieties around the authenticity of memory and mourning. The first characteristic results from the long time span between the death of these soldiers and the exhumation of their bodies, and is the extent and quality of inter-generational transmission of memory in the Fromelles family. From informant interviews, the condition of postmemory can be identified in many of the relatives engaged with the Fromelles Project (Scates, 2016). Postmemory is a concept developed in Holocaust studies to characterize the state of those generations born after the Holocaust who have no firsthand memory of these events but whose psychic and affective landscape is profoundly shaped by the loss and suffering sustained in that period (Hirsch 2008; 2012). Of course, there are evident and important differences in the historical contexts of World War I and the Holocaust. However, the state of postmemory is still a useful way of thinking about how individuals actively construct their relationship with the past, engaging with the traumas of past generations in order to mourn those losses, make sense of horrific events, and construct their own identity in relation to the preceding generations of their family (Scates, 2016).

The second characteristic is the highly elaborated and visible commemorative tradition maintained in the village of Fromelles by the local population, where the sacrifice of the Australian Imperial Force, and by extension, all things Australian, are celebrated and embraced. The honour accorded to the dead by locals in Fromelles, and around the Western Front more widely, is profoundly important to the Australian relatives of the dead, and strongly informs their perception that the dead will be well-cared for in Fromelles. The existing commemorative traditions encountered in France, that predate the exhumations, are perceived as an important touchstone of authentic mourning. The apparently unbroken local traditions of commemoration at Fromelles are a source of comfort and inspiration to relatives when constructing their own forms of mourning for the newly discovered dead at Fromelles. 
A third feature is the characterization of the battle of Fromelles as a disastrous military blunder, the dead of Fromelles as neglected by the authorities, and the perception that the whole Western Front campaign is marginalized within Australian war heritage, particularly when compared to the Dardanelles campaign which has dominated national consciousness for several generations (Macleod 2002). Raising the public profile of the battle and gaining the widest possible recognition for the sacrifices at Fromelles are a strong motivation for many of the relatives. The horrific casualties suffered by Australian forces whilst under British command, and the perception by many relatives that the Australian contribution to both World Wars is insufficiently recognized in British war heritage, compounds the profound sense of injustice associated with this battle. This means that the Fromelles families, and a wider community of supporters, actively seek a rupture with the past in terms of the status and treatment of the dead. Yet these ruptures may threaten the unique qualities of the locale and the emotions it inspires. These tensions will be explored more closely in this article through an analysis of excerpts of interviews with relatives engaged in the Fromelles Project.

\section{Postmemory and the Fromelles Families}

With the centenary of this battle falling in July 2016, the long time period between death and discovery in the case of the Fromelles dead, intensifies concerns with continuity and authenticity for the relatives of the soldiers. In the majority of these families, multiple generations have passed and there is no one still surviving who has a firsthand memory of the dead. Furthermore, the patchy contemporary knowledge of the circumstances of the battle in 1916, and the way some families were recruited to the Fromelles Project by genealogists who tracked them down through archive records, mean that a proportion of the families involved have no pre-existing knowledge of their soldier, no inter-generational transmission of memory, or family tradition pertaining to the mourning and commemoration of the Fromelles dead. Others have imbibed a sense of the mourning and loss that surrounded these deaths, but may have many factual questions on the circumstances of death still unanswered. Those who have inherited a strong sense of the impact of the death on their family may also feel that the exhumation and reburials have come too late for those relatives of the dead soldier who most needed comfort and resolution, and feel the responsibility of mourning on the behalf of the bereaved generation who are themselves long dead. The wish that parents or grandparents were still alive to know that the bodies had been recovered, was a near universally expressed sentiment in these interviews:

'It felt unbelievable. When we got that phone call, I just wished that my mother had been around to experience it. It was just incredible and I couldn't believe it.' (KI)

Many individuals were highly self-reflective, to the point of self-consciousness, grappling with the contradictions inherent in mourning for someone they had never known, and not wishing to make a possessive claim of ownership or privileged knowledge of the dead. Some individuals expressed doubts about the rationality and authenticity of their own mourning and described a struggle to calibrate ones emotional response to the entirely novel situation of discovering an ancestor in a mass grave on the Western Front. A very strong tendency throughout these interviews, which I argue 
is characteristic of a postmemorial state, is that the primary expressions of mourning were not explicitly focused on the death of the soldier at Fromelles. Rather, there was an intensive focus on the impact of the soldier's death on the wider family, and an assertion that they were grieving for the grief endured by others (Ziino, 2010). Many individuals were profoundly moved by the stories they had inherited of the parents, wives and children of the dead soldiers who were bereaved by the battle of Fromelles, expressing an imaginative and empathetic connection with the past, and identifying the shadow it cast in their family (Damousi, 1999). In this interview excerpt, BM expresses a connection with her great grandmother who lost two sons in this period, one at Fromelles. In fact, her form of speech addresses the dead directly, but on behalf of her grandmother, and at the same moment she reflects on how this loss reverberated through the generations and shaped the lives of those affected:

'But all I could think about was my great grandma and how she must have felt and how if I had been in those depths of depression, I would have suicided. How did my great grandmother survive, how had she suffered. I felt a huge connection, a point of empathy, across all those thousands of miles and all those 94 years [...] Boys, you were never forgotten, you never will be forgotten, your mother loved you more than she could ever show and more than she could bear, and that your loss was felt through the generations. My great grandparents didn't have a happy marriage, and my grandparents didn't have a happy marriage and I think that loss was part of it.' (MB)

A further aspect of this postmemorial state is the struggle to identify the right way to mourn and to evaluate competing claims over the dead. The practicalities of a large scale exhumation and reburial of this kind throw up myriad decisions that will fall to the relatives of the dead regarding how to engage with the process and how to commemorate these soldiers. These are novel situations for which there is no preparation or guidance (Crossland, 2009). It is not directly comparable to mourning the unknown dead at a war memorial, neither is it comparable to planning the funeral of a relative that one has known in life. It elicits a series of invented traditions and new forms of vernacular mourning that blend with the scientific and military protocols of the exhumation and reburial process. Many of the Fromelles families feel the responsibilities of these decisions keenly. Another effect of the long time period that has elapsed between the battle and the exhumation is that the network of relatives for some soldiers has grown very large. There may be multiple family members with the same degree of familial closeness who feel a sense of connection to the dead and wish to be consulted as part of the exhumation and reburial process. Due to their young age at death, many of the soldiers are not survived by direct descendants, but by the descendants of their siblings, the great nieces and nephews. This can lead to competing claims within family groups regarding who should be a point of contact, who should speak at the grave, who should donate DNA, who should select an epitaph for the headstone, and who should retain family memorabilia. These kinds of tussles over who are the most authentic descendants of the dead, and who has the authority to speak for the dead, and the previous generation that mourned them, is exemplified in this excerpt:

'We got together to decide what should go on the headstone. We were emailing ideas. It got a little bit out of hand because my cousin $\mathrm{N}$ was nominated to be spokesperson for the whole family, for what to put on the grave. The army had nominated her, really. I don't know why. We were supposed to liaise through 
her and she came up with a dedication and my cousin B said 'No!' He said 'my mother was closest to him, she named me after him and always had his photo, and I should be the one to choose the inscription.' He said his mother had grieved more. I said 'look, my mother was very close to him too!' And he said 'not as close as my mother, my mother carried his photo with her everywhere.' She had carried a locket [...] but we settled it in the end.' (KI)

My strong impression of interviewing Fromelles families was that many were managing to navigate these competing claims with sensitivity and many felt their family had been unified by collective decision-making. Certainly, for many participants, the focus on a shared ancestor was a catalyst for family reunions and the reaffirmation of familial bonds. However, there was no doubt that these sensitive negotiations were stressful and constantly raised challenges and self-reflection over who were the 'real' or most worthy descendants and who possessed the most authentic knowledge and emotional connections to the past. It is apparent that given the postmemorial anxieties outlined above, the seemingly unbroken tradition of commemoration amongst the local inhabitants at Fromelles is extremely significant for the relatives of the dead. As will be discussed in detail, the commemorative culture at Fromelles is experienced as authentic, comforting, and inspiring for those relatives grappling with both the emotional and practical challenges of the discovery of an ancestor at Fromelles.

\section{Lost Graves and a Forgotten Battle: Gaining Recognition for the Fallen of Fromelles}

The events which unfolded at Fromelles in July 1916 during the battle and its aftermath remain highly contentious. The treatment of the Australian soldiers who fought and died in the battle and the subsequent treatment of their remains continues to elicit strong feelings of anger amongst relatives of the dead, and the keen sense of an historical injustice that is yet to be righted. Beyond the staggering scale of casualties at Fromelles, which, in the context of World War I, is not unique, there are multiple factors that compound the sense of injustice surrounding this battle. These factors bring a further element of complexity to the commemoration of Fromelles. The articulation of these injustices by the Fromelles families are a strong illustration of how commemorating those that died fighting for the British Empire, also necessitates a confrontation with the colonial power relations that pertained at that time (Blair, 2001), and a reflection on how national identities and relationships have shifted in the post-colonial era.

Amongst the relatives I interviewed was a near-universal perception that the horrific loss of life at Fromelles was the result of a catastrophic military blunder by British commanders, with the Australian forces instructed to capture an unassailable position, and with multiple compounding errors on the timing and strategy of the battle that caused further loss of life. Linked to this, is the firm conviction that the carelessness exhibited in this battle was related to the fact that the Australian troops were treated as dispensable by British commanders.

'It was pushed under the carpet. It was such a military disaster. They pushed a thousand people up over the trenches. Less than 100 came back the first time and they sent another 1000 out [...] I felt angry during the ceremony. I feel angry with the British. The British attitude was let Australia go. Even in World 
War II, when Japan attacked Australia, the British would have let Australia go.' (KI)

There is also a widely-expressed view that a conspiracy of silence has surrounded this battle from its immediate aftermath onward to the present day. There was very little accurate reporting of the losses at the time. Confusion around the nomenclature of the location and the battle contributed to a lack of awareness of what had transpired there, and fuelled suspicions of a cover-up. There is also a strongly-felt anger amongst many Fromelles families that Australian war heritage in both public discourse and popular imagination has been dominated by Gallipoli, to the exclusion of the Western Front:

'No one's heard of Fromelles. I studied Australian history and I never heard it mentioned. Anzac day is on the day of Gallipoli. What date do the British use? But you British don't have any particular battle that you have to remember, maybe Agincourt or 1066! [...] The live service from Villers Bretonneux is shown on TV now, so it makes people focus on the Western Front. It used to just be broadcast from Gallipoli.' (RB)

Furthermore, whilst British war heritage does focus on the Western Front, it fails to acknowledge the battle of Fromelles in particular, and more generally, the contribution of Anzac forces. There is anger at the perceived ignorance or complacency in Britain today surrounding this contribution. This anger is often framed in terms of a wider anger at the unequal power balance of the colonial relationship that pertained at the time of the battle:

'I don't think the British are that interested in us. They don't have to be interested in the land of the convicts. We have to be interested in them, because of our status 100 years ago, flying the flag. We were treated shabbily [...] But I don't think that's particular to Australia. That's just how Britain treats other countries.' (MRB)

These multiple layers of historical injustice are highly emotive for the Fromelles families and make them passionate advocates for the dead (Renshaw, 2013). The sentiment 'No one's heard of Fromelles', is expressed, in some form, in nearly every interview with family members, and many feel intensely committed to correcting this perceived omission. Many relatives talk about raising the status of Fromelles, even expressing the idea that 'every Australian' should visit, that the site should become incorporated into the existing trail of battlefield tourism or cemetery pilgrimages, and that the village deserves to be allocated resources to help it maintain this heritage and welcome greater visitor numbers. The contrast between the British and French commemoration of the battle is a central theme that surfaces repeatedly in interviews with the Fromelles families. This heightens the emotional significance of the local commemoratives practices that relatives of the dead encounter when they visit Fromelles.

\section{'The Manners and Charm': The Commemorative Culture at Fromelles}

It is useful to briefly describe the commemorative culture at Fromelles. In addition to the formal architecture of the Australian Memorial Park which incorporates the burials 
at VC Corner, and the iconic and emotionally affecting 'Cobbers' statue, there are more vernacular forms of commemoration that make a deep impression on Australian visitors. The village school is central focus for expressing the links between Australia and Fromelles. The weathervane is in the shape of a kangaroo and there are two clocks side by side to show the time in both Australia and France. The Australian flag, and bunting depicting the Australian flag, bedeck the school and other public areas when visitors are welcomed. There are schoolchildren's drawings depicting individual soldiers who fought in the battle and murals all over the school showing a range of images and messages relating to the battle. The school is a central focus, largely by dint of being a primary public building in the settlement, but the significance of the school runs deeper for many Australian visitors, who remark upon the involvement of children in the commemorative culture of Fromelles, reinforcing a fictive kinship between the dead and the local inhabitants (Piehler, 1994; Winter, 1995) and showing that the baton is being passed to the next generation of Fromelles residents.

Since 1990, there has also been a Fromelles 'museum'. This is an ad hoc collection of artefacts connected to the battle, which have been picked up from the surrounding fields and stored above the village hall. Equally important, are the less tangible elements of this experience, the warm human interactions, the care and hospitality, epitomized by the Mayor of the village, which many visitors found deeply moving and memorable. The unique nature of Fromelles, and its memorial culture was not just a passion for those Australians who had visited in person. Many others who had not been could also describe it vividly and were equally passionate about the special character of the place. This was either from accounts and photographs circulated by family members who had visited or by engaging with news media, social media, and online groups devoted to Fromelles. It is also important to note that French historians have called in to question whether local memorial practices on the Western Front really are an unbroken tradition dating back to the postwar period (Wellings, 2014) or whether these communities are just as susceptible to the vicissitudes of memory politics as communities in Britain or Australia. However, the fact that relatives of the dead perceive local customs as enduring across generations is more significant in shaping their experience of visiting.

The majority of relatives in the interviews I conducted made the assertion that it was historically right and fitting that the bodies remain in Fromelles. Some referred to it as a 'little piece of Australia', 'more Australian than Australia', or 'a home from home'. Even those relatives who had contemplated repatriating the bodies, commented that the dead were better cared for, and their memory more celebrated, in Fromelles than in Australia:

'At first, I really wrestled with the idea that they wouldn't bring them home. I'm a mother and I wanted to do it for their mothers, even though their mothers have now passed and it doesn't matter that we're not their actual mothers. I didn't think they were like the other soldiers, because other soldiers had their names, or at least a headstone. But the Fromelles dead, they deserved to be identified. Because that's what we do now, we bring our dead home and for me, it was now, because that's when we were discovering them. But then we went to Fromelles and they're not alone, they are very much part of that community and they are more well cared for there than they would be here, and I got a lot closure from going there. They are better off there.' (SA) 
It is important to focus on the micro-level of interpersonal relationships forged between visitors and Fromelles inhabitants. It is worth considering this extended excerpt in full because it expresses eloquently, and vividly, the emotion surrounding these exchanges. These words capture the affection for new friends, the excitement of encounters across cultural and linguistic barriers, and also suggest something of the mayhem of a large, high-profile event unfolding in a small village:

'We stayed with a French family and it was fabulous. We had much more contact with the Mayor. His wife was delightful. It was just so French, so French, it was like dropping in to another planet. They couldn't do enough for us and we were thoroughly spoiled [...] She cooked us food from every region in France. And we're on a promise that we must be back in 2016. I am much more relaxed now and we are part of their family and I know that all the young men, identified or unidentified, they have a family there, so I know they're all right. I saw it with my own eyes how they're honoured. The poor Mayor almost going out of his head dealing with Royalty and Governors General. He's there in his little sash. He took us out for dinner and we weren't allowed to speak anything but French. Because they had spoken English for a whole week and we managed it!' (SA)

In the above excerpts, it is important to note that there is no one commemorative act or monument that is singled out. Rather the sense of human connections with the dead are highlighted; 'they have a community' and 'they have a family there', are representative of many speakers' feelings. The intense sociality and cultural immersion of visiting Fromelles makes it a key life experience for many relatives of the dead. Many make reference to the aspects they find most typically French, particularly the experience of food and alcohol, the capacity to cater for large crowds, speeches and toasts, a sense of etiquette and occasion. Several describe feeling charmed by the place and evoke a kind of aura associated with their time there:

'We're going back there, and we've just formed a love affair with the place. People were just fantastic, really wonderful. My son is in Bali at the moment with his girlfriend, and even he is breaking his neck to get back there. The culture, sounds, sights. The elegance of continental Europe, the manners and charm.' (CJE)

A more critical perspective on these kind of sentiments is expressed by historian Marilyn Lake who warns that this kind of heritage can be both "nationalist and internationalist at the same time' and that one of the attractions of military family history is it affords 'the pleasure of travel overseas' (Lake quoted in McKenna, 2012). Whilst it is vital to stay clear-eyed about nationalism and sentimentalism in Anzac heritage (Lake et al 2010), this phrase suggests a somewhat superficial or passive encounter through travel, whereas the majority of informants characterized their experiences within Fromelles itself as distinct from tourism. The quality of personal interactions with Fromelles inhabitants, and the realization of global and historic interconnections between them, left people profoundly moved. The 'pleasure of travel' also fails to reflect the degree of emotional investment, trepidation, and sense of familial and historical responsibility that relatives felt about their trip to Fromelles. 
Many relatives express a deep appreciation, and even awe, at the way local inhabitants have maintained the memory of the battle and the warmth with which locals continue to welcome and host visitors to the village. There is a clear emphasis on the authenticity of the memorial culture at Fromelles. The perceived authenticity of these encounters is a highly-valued aspect of the experience. By its ineffable nature, it is hard to describe this aspect precisely or explicitly, but it is revealed by phrases such as 'just so French', or 'the manners and the charm'. In a number of other interviews, relatives highlight the question of authenticity, by contrasting it with their experiences of other locales, such as Gallipoli, and other experiences, such as official museums and guided tours which implicitly lacked authenticity, and thus lacked the affective power of visiting Fromelles:

'I hate going on conducted tours, but I found one guy, he runs his own battlefield tours and he showed me, there was a little museum in Fromelles, and you go upstairs, and they've been digging up things for years, all the things they've collected. It was very interesting, all the bullets and the gas masks and just bits and pieces, their spoons, forks, dixies, cups, they had a section for the Germans and another for the New Zealanders. I found the plates and the utensils very moving, because they had belonged to someone, a person who had actually used those things.' (DM)

It is useful to reflect on what the speaker highlights about the 'little museum' because it is applicable to the wider experience of visiting Fromelles. It is hidden away above the town hall, and must be discovered. The museum is small, open by appointment only, with visitors going individually or in small groups. This confers a sense of intimacy, of having a unique or privileged experience at Fromelles, away from the crowds found at other memorial sites on the Western Front. The objects have been collected and organized by locals, so it is a grassroots and vernacular form of heritage. Unlike the majority of museums or visitors' centres, objects can be handled and none are behind glass. The real everyday objects have an affective power precisely because they were owned and touched by soldiers who fought at Fromelles. They possess a sense of immediacy, and a direct connection to the past, unmediated by officialdom or ceremonial practices (Saunders 2002; Whitford \& Pollard, 2009).

In 2014, a new purpose-built museum was opened, immediately adjacent to the new CWGC cemetery that was created in 2010 . The new museum employs the contemporary architectural style of jagged, abstract forms, frequently seen in modern museums and galleries, particularly those associated with the traumatic past. The old collection has been re-displayed there along with a considerable volume of professionally produced text to present information and interpretation to the visitor. A detailed account of the discovery of the grave, the exhumation, and construction of the new cemetery are also presented in the museum. The scale of the building, parking and facilities has been dramatically expanded to accommodate the steep rise in visitor numbers since 2010. The re-development at Fromelles is not an isolated example but are part of a large-scale investment in Australian military heritage on the Western Front (Sumartojo, 2014). Recent critical scholarship on this investment has pointed to the risks of commodifying memory and imposing a homogenized nationalist narrative onto local commemorations (Beaumont, 2015; Fathi, 2014; Van der Auwera \& Schramme, 2014). These particular changes at Fromelles; the fundamental change of exhuming and reburying the dead, and the associated changes 
to the visitor experience, such as the new museum, can be considered in light of what informants say on the theme of continuity and authenticity.

\section{The Development of Fromelles as a Threat to Continuity and Authenticity}

There are recurring themes or tropes in the interviews I conducted with Fromelles families that suggest a strong concern with ensuring continuity in the treatment of the dead, even whilst espousing radical changes to the site. These recurring tropes include a particular awareness of the order in which the bodies have lain in the mass grave. When the new cemetery was created, a decision was taken by the CWGC to rebury all the bodies in the same order, ensuring that the dead soldiers would still be in close proximity to the same comrades. This was singled out for approval by many relatives who referred to the dead as 'mates' and implied that special bonds that had formed by fighting and dying in battle, but also formed post-mortem within the mass grave, should be maintained in the new cemetery. This notion of a 'fellowship of the grave' is by no means unique to Fromelles and can be noted in other mass grave investigations (Renshaw 2010; Renshaw 2011). Some relatives commented positively on the very close proximity of the new cemetery to the old mass graves. My interpretation of the frequency with which relatives emphasized the proximity, inter-visibility, and lines of sight, between different key locales at Fromelles (church, school, mass grave, and cemetery) is that it constitutes a form of verbal binding, repeatedly asserting a recursive link between old and new, and justifying the relocation of the bodies.

They particularly noted the aural environment, commenting that the dead could still hear the same sounds in their new resting place. The idea of the dead 'hearing' these ambient sounds draws on a common figuration of death and burial as sleep (Renshaw 2011). A specific focus was the sound of the church bells and the sound of children in the village. These were both deemed reassuring and homely sounds that would continue to comfort the dead and provide continuity between their old and new burials. The strong approval of the role of the Fromelles children and their school can also be interpreted as a concern for continuity, as the engagement of children in commemorating the dead is a kind of insurance that these traditions will be maintained in the future (Winters, 1995). A large number of relatives expressed their gratitude to the landowners of the site of the original mass graves who had undertaken to preserve it, in perpetuity, so it would never be redeveloped or farmed. There was a widely held idea that the now-empty mass grave was also a site of memory to be protected.

However, at odds with these assertions of continuity, is the very deep conviction that battle of Fromelles and those who had died there had suffered from official cover-ups, neglect and the ignorance of the wider population in Australia and Britain. The led the frequently-expressed assertion that more people should learn about Fromelles, that more people should visit to experience the place for themselves, and that the dead deserved more public recognition. A common opinion was the Australian, British and French authorities should allocate more resources to the site and to other forms of public recognition such as the creation of memorials to Fromelles in other locations, or the adding of the battle to existing memorials and museum displays. From this point of view, the dramatic transformations in the Fromelles site, which have now gone far beyond the recovery of the bodies, and the accompanying increase in public profile and 
visitor numbers, are a fulfillment of this impetus to raise the status of the battle and its fallen.

\section{Conclusion}

The existing highly-elaborated memorial culture encountered in the village of Fromelles and on the Western Front more broadly, is extremely significant in providing a sense of continuity and authenticity which can help bridge temporal and affective distances, resonating with the postmemorial anxieties outlined above. The fact that the commemorative traditions in Fromelles are vernacular and come from the grassroots of the village inhabitants make them an important counterpoint to the encounters with officialdom that relatives of the dead must navigate as part of the exhumation process. Visitors value the interpersonal connections across national and linguistic boundaries, and the intimate, direct and unmediated experiences they have there. However, the commemorative culture at Fromelles also provokes distinct anxieties about how to ensure continuity, and minimize rupture, in the treatment of the dead. Since the discovery of the mass graves, there is a clear tension between the unique commemorative culture at Fromelles and its ever-growing public profile, along with ever-growing visitor numbers. As the site becomes accessible to more visitors, an increasingly formalized and commodified commemoration of the dead threatens the particular kind of affect and charm possessed by the local commemorative culture, which is so valued by relatives of the dead.

Word count: 6383

\section{References}

Beaumont, J., 2015. Australia's Global Memory Footprint: Memorial Building on the Western Front, 1916-2015. Australian Historical Studies, 46(1), 45-63.

Blair, D., 2001. 'Those Miserable Tommies': Anti-British Sentiment in the Australian Imperial Force, 1915-1918. War \& Society, 2001 19:1, 71-91.

Cobb, P., 2007. Fromelles 1916, Stroud: Tempus.

Corfield, R., 2009. Don't Forget Me Cobber: The Battle of Fromelles, Victoria: Miegunyah Press.

Crossland, Z., 2009. 'Acts of Estrangement. The Post-mortem making of Self and Other'. Archaeological Dialogues, 16 (1), 102-125.

Damousi, J., 1999. The Labour of Loss Cambridge: Cambridge University Press.

Fathi, R., 2014. 'A Piece of Australia in France': Australian authorities and the commemoration of Anzac Day at Villers-Bretonneux in the last decade. In Sumartojo, S., \& Wellings, B. (Eds.) Nation, Memory and Great War Commemoration:

Mobilizing the Past in Europe, Australia and New Zealand. Oxford: Peter Lang, 273290. 
Hirsch M., 2012. The Generation of Postmemory: Writing and Visual Culture After the Holocaust, New York: Columbia University Press.

Hirsch, M., 2008. 'The Generation of Postmemory' Poetics Today 29 (1) 103-128.

Jones, P., 2010. 'The Use of DNA Profiling' in J. Summers (ed) Remembering Fromelles: A New Cemetery for a New Century, Maidenhead: CWGC Publishing 6368.

Lake, M., Reynolds, H., McKenna, M. \& Damousi, J., 2010. What's Wrong with Anzac? The Militarisation of Australian History. Sydney: UNSW Press.

Lindsay, P., 2008. Fromelles: Australia's Darkest Day and the Dramatic Discovery of our Fallen World War One Diggers, Prahran: Hardie Grant Books.

Loe, L., 2010. 'Remembering Fromelles'. British Archaeology, 111 (March/April), $36-41$.

Macleod, J., 2002. The Fall and Rise of Anzac Day: 1965 and 1990 Compared. War and Society, 20 (1), 149-168.

McKenna, M., 2012. Lest We Inflate: Why do Australians lust for heroic war stories? The Monthly: Australian Politics, Culture and Society (January).

Piehler, G.K., 1994. The War Dead and the Gold Star. In Gillis, J. (ed.)

Commemorations: The Politics of National Identity. Princeton, N.J.: Princeton University Press, 168-85

Pollard, T., Barton, P. \& Banks, I., 2007. The Investigation of Possible Mass Graves at Pheasant Wood, Fromelles, GUARD Report 12005.

Renshaw, L., 2010. Missing Bodies Near-at-Hand: The Dissonant Memory and Dormant Graves of the Spanish Civil War. In Bille, M. , Hastrup, F. and Flohr Sorenson, T. (eds.) An Anthropology of Absence: Materializations of Transcendence and Loss. New York: Springer, 45-61.

Renshaw, L., 2011. Exhuming Loss: Memory, Materiality and Mass graves of the Spanish Civil War. Walnut Creek CA: Left Coast Press.

Renshaw, L., 2013. The dead and their public: Memory campaigns, issue networks and the role of the archaeologist in the excavation of mass graves. Archaeological Dialogues, 20(1), 35-47.

Saunders, N.J., 2002. Excavating Memories: Archaeology and the Great War, 19142001 Antiquity 76 (1), 101-8.

Scates, B., 2016. The Unquiet Grave: Exhuming and Reburying the Dead of Fromelles in K. Reeves, G. Bird, L. James, B. Stichelbaut \& J. Bourgeois Battlefield Events: Landscape, Commemoration and Heritage. London: Routledge,13-27. 
Scully, J.L., \& Woodward, R., 2012. 'Naming the Unknown of Fromelles: DNA profiling, ethics and the identification of First World War bodies' Journal of War and Cultural Studies 5 (1), 59-72.

Sumartojo, S., 2014. Anzac kinship and national identity on the Australian remembrance trail. In Sumartojo, S., \& Wellings, B. (Eds.) Nation, Memory and Great War Commemoration: Mobilizing the Past in Europe, Australia and New Zealand. Oxford: Peter Lang, 291-306.

Summers, J. (2010) Remembering Fromelles: A New Cemetery for a New Century. Maidenhead: CWGC Publications.

Van der Auwera, S. and Schramme, A., 2014) Commemoration of the Great War: A Global Phenomenon or a National Agenda? Journal of Conflict Archaeology 9 (1), 315 .

Verdery, K., 1999. The Political Lives of Dead Bodies: Reburial and Postsocialist Change, New York: Columbia University Press.

Wagner, S. and Rosenblatt, A. (2016) Known Unknowns: Forensic Science, the Nation State and the Iconic Dead In Stojanowski, C.M. and Duncan, W.N. Studies in Forensic Biohistory. Cambridge: Cambridge University Press, 237-266

Wellings, B., 2014. Lest You Forget: Memory and Australian Nationalism in a Global Era In Sumartojo, S., \& Wellings, B. (Eds.) Nation, Memory and Great War

Commemoration: Mobilizing the Past in Europe, Australia and New Zealand. Oxford: Peter Lang, 45-60.

Whitford, T. \& Pollard, T., 2009. 'For Duty Done: A WWI Military Medallion Recovered from the Mass Grave Site at Fomelles, Northern France'. Journal of Conflict Archaeology, 5 (1), 201-229.

Winter, J., 1995. Sites of Memory, Sites of Mourning: The Great War in European Cultural History. Cambridge: Cambridge University Press.

Ziino, B., 2010. A lasting gift to his descendants: Family memory and the great war in Australia. History \& Memory, 22 (2), 125-146. 